\title{
Distribusi Spasial Total Padatan Tersuspensi Puncak Musim Hujan Di Permukaan Perairan Teluk Benoa, Bali
}

\author{
I Gede Surya Risuana a*, I Gede Hendrawan a, Yulianto Suteja a \\ a Program Studi Ilmu Kelautan, Fakultas Kelautan dan Perikanan, Universitas Udayana, Kampus UNUD Bukit Jimbaran, Bali 80361, Indonesia \\ * Penulis koresponden. Tel.: +62-214-698-4673 \\ Alamat e-mail: surya.risuana@gmail.com
}

Diterima (received) 21 Agustus 2016; disetujui (accepted) 10 Agustus 2017; tersedia secara online (available online) 12 Agustus 2017

\begin{abstract}
Benoa Bay is semi- enclosed bay, which has embouchures. The existence of embouchures are able to contribute the Total Suspended Solid (TSS) to the Bay. As the one of pollution parameter, TSS could be influencing the ecosystem of coral reefs, seagrass, and the existence of dissolved oxygen. This research was aimed to know the spatial distribution of TSS on the surface layer in Benoa Bay. Sample was taken on January 2016, in flood and ebb. TSS was analyzed using gavimetry method based on SNI No. 06-6989.3-2004. Spatial distribution was analyzed by interpolation methodInverse Distance Weighted (IDW). The concentration range of TSS on January in ebb to tide and tide to ebb was 22.44 $\mathrm{mg} / \mathrm{L}$ to $261.33 \mathrm{mg} / \mathrm{L}$. The highest distribution in flood was dominated in around of embouchures. It was suspected by inputs of suspended matter from land to the bay. In tide to ebb condition, TSS concentration was high in some areas, such as around the embouchures, midlle and mouth area of bay. The high concentration was suspected by pattern of tidal current in Benoa Bay. The pattern of current in ebb was leaving to the mouth of Benoa Bay, therefore the TSS concentration dispersed to the mouth of the bay.
\end{abstract}

Keywords: Benoa Bay, TSS, Spatial distribution

\begin{abstract}
Abstrak
Teluk Benoa merupakan teluk semi tertutup yang memiliki beberapa muara sungai. Adanya muara sungai tersebut akan memberikan sumbangan terhadap total padatan tersuspensi (TSS) di perairan. Total padatan tersuspensi merupakan salah satu parameter pencemaran yang mempengaruhi ekosistem terumbu karang, lamun dan ketersediaan oksigen. Tujuan penelitian ini adalah mengetahui distribusi spasial total padatan tersuspensi di permukaan perairan Teluk Benoa. Pengambilan sampel dilakukan pada bulan Januari dengan kondisi surut menuju pasang dan pasang menuju surut. Metode yang digunakan untuk analisis TSS yaitu metode gavimetri dengan acuan SNI No. 06-6989.3-2004 dan untuk analisis spasial menggunakan metode interpolasi Invrse Distance Weighted (IDW). Konsentrasi TSS pada bulan Januari pada saat surut menuju pasang dan pasang menuju surut berkisar antara 137.11 mg/L hingga mencapai $403.33 \mathrm{mg} / \mathrm{L}$. konsentrasi TSS di sungai yang bermuara di Teluk Benoa berkisar antara 22.44 mg/L hingga mencapai $261.33 \mathrm{mg} / \mathrm{L}$. Persebaran konsentrasi TSS tertinggi pada saat surut menuju pasang didominasi terdapat di sekitar muara sungai yang bermuara di Teluk Benoa. Tingginya konsentrasi di sekitar muara diduga dikibatkan oleh adanya masukkan bahan-bahan tersuspensi dari daratan yang terbawa oleh aliran sungai. Pada kondisi pasang menuju surut konsentrasi TSS tertinggi terdapat di sekitar muara sungai, bagian tengah teluk dan bagian mulut teluk. Tinggi konsentrasi TSS di bagian tengah teluk dan mulut telu diduga diakibatkan oleh pola pergerakan arus di teluk Benoa. Dimana pada saat pasang menuju surut pola arus di Teluk Benoa menuju ke luar teluk, sehingga konsentrasi TSS akan lebih tersebar di tengah teluk hingga ke luar teluk.
\end{abstract}

Kata Kunci: Teluk Benoa; TSS; Distribusi spasial 


\section{Pendahuluan}

Teluk Benoa merupakan perairan semi tertutup yang memiliki fase dua kali pasang dan dua kali surut dalam waktu 24 jam (semi diurnal). Luas teluk Benoa yaitu sekitar 1.998,1 Ha (Sudiarta et al., 2013). Teluk Benoa merupakan daerah tempat bermuaranya beberapa sungai yaitu sungai Bualu, sungai Sama, sungai Mati, sungai Badung, sungai Buji dan sungai Loloan (Sudiarta et al., 2013). Adanya sungai tersebut akan berpotensi menyebabkan terjadinya pencemaran yang diakibatkan oleh aktivitas manusia seperti kegiatan industri, rumah tangga, dan pertanian akan menghasilkan limbah yang memberi sumbangan pada penurunan kualitas air sungai (Suriawiria, 2003).

Menurut Marganof dkk. (2007) limbah yang terdapat dalam perairan sungai dapat berupa total padatan tersuspsesi. Total padatan tersuspensi adalah padatan dalam air, termasuk partikel tanah (tanah liat, lumpur, dan pasir), alga, plankton, dan zat lainnya dengan ukuran berkisar antara 0.004 $\mathrm{mm}$ (tanah liat) sampai $1.0 \mathrm{~mm}$ (pasir) (Ohrel dan Register, 2006).

Tingginya konsentrasi total padatan tersuspensi pada suatu perairan akan mengakibatkan berkurangnya oksigen dalam perairan akibat penurunan aktivitas fotosintesa dari tumbuhan laut baik yang mikro maupun makro (Bilotta and Brazier, 2008). Berkurangnya oksigen dalam perairan akan mengakibatkan ikanikan menjadi mati (Mitchell and Stapp, 2008).

Menurut Foster et al., (2002) tingginya konsentrasi pencemaran dapat diakibatkan oleh aliran arus yang rendah. Hendrawan et al., (2005) menunjukkan arus residu yang dimiliki teluk Benoa cenderung memiliki nilai yang tinggi. Tingginya arus residu tersebut berimplikasi terhadap waktu yang dibutuhkan untuk melakukan pembilasan polutan sehingga waktu untuk melakukan pertukaran masa air dari luar teluk ke dalam teluk akan membutuhkan waktu yang lebih lama. Kejadian ini akan berakibat dengan penumpukan polutan di wilayah dalam teluk, dan akhirnya akan menurunkan kualitas perairan Teluk Benoa salah satunya adalah padatan tersuspensi.

Tingginya konsentrasi padatan tersuspensi berpotensi mempengaruhi biota yang ada di dalam kawasan teluk Benoa karena merupakan daerah asuhan bagi ikan (nursery ground), tempat mencari makan (feeding ground) dan tempat pemijahan (spawning ground). Sedangkan diluar kawasan teluk Benoa terdapat ekosistem yang sangat rentan akan tingginya padatan tersuspensi. Ekosistem yang dimiliki di luar kawasan teluk benoa yaitu ekosistem terumbu karang dan ekosistem lamun yang membentang dari Sanur hingga Tanjung Benoa (Sudiarta et al., 2013).

Mengingat sangat besarnya dampak yang ditimbulkan oleh total padatan tersuspensi terhadap potensi yang dimiliki di dalam kawasan teluk dan di luar kawasan teluk (Wilber and Clarke, 2001). Maka perlu adanya penelitian mengenai distribusi spatial dan temporal total padatan tersuspensi dengan harapan dapat mengetahui persebaran total padatan tersuspensi di dalam kawasan teluk Benoa. Persebaran total padatan tersuspensi sangat peting diketahui agar dapat mengelola dan mengurangi sumber dari pencemar tersebut. Untuk mendapatkan hasil distribusi spasial total padatan tersuspensi maka perlu adanya interpolasi.

Interpolasi adalah metode atau fungsi matematika yang digunakan untuk memperkirakan nilai di lokasi yang tanpa nilai. Interpolasi spasial mengasumsikan data atribut secara terus menerus dalam sebuah ruang, hal ini memungkinkan estimasi atribut pada setiap lokasi di dalam batas data (Li and Heap, 2014). Metode interpolasi yang digunakan adalah metode interpolasi Inverse Distance Weighting (IDW). Dimana dengan metode ini sangat mudah digunakan dan efisien serta dapat mengontrol karakteristik interpolasi dengan membatasi titiktitik masukan, dapat menghapus titik yang lokasinya terlalu jauh dan tidak memiliki korelasi spasial dan dapat menentukan titik yang akan digunakan secara langsung atau dapat ditentukan berdasarkan jarak yang ingin di interpolasi (Xie et al., 2011; Azpurua and Ramos, 2010; Pramono, 2008).

\section{Metode Penelitian}

\subsection{Waktu dan tempat pengambilan sampel}

Penelitian ini dilakukan pada bulan Januari 2016. Lokasi penelitian dilakukan di teluk Benoa, Bali seperti pada Gambar 1. Jumlah titik sapling dalam penelitian ini yaitu berjumlah 42 titik dimana 36 titik berada di dalam teluk dan 6 titik di sungai. 


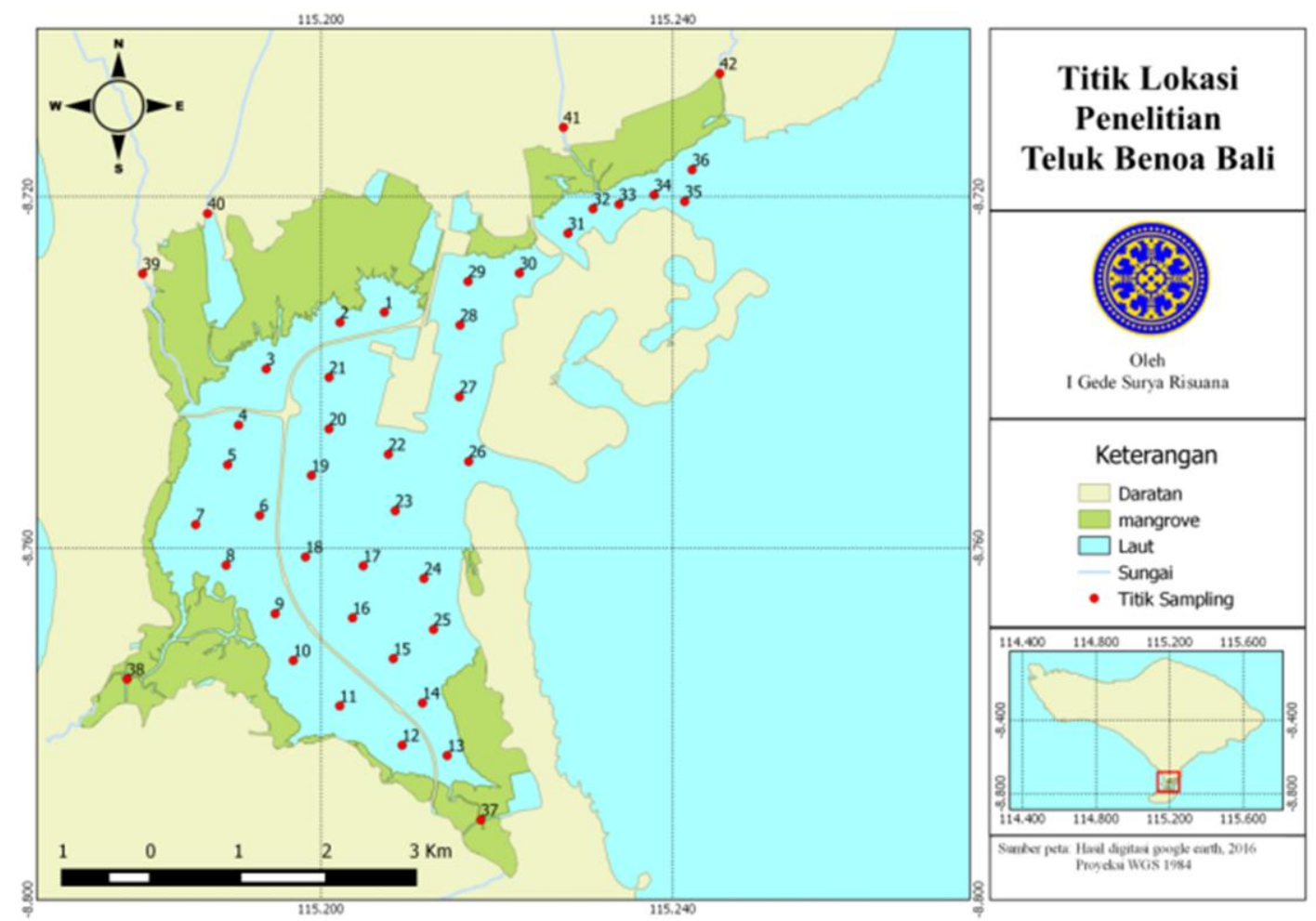

Gambar 1. Areal penelitian dan titik lokasi pengambilan sampel

Analisis padatan tersuspensi dilakukan di Laboratorium Ilmu Kelautan Fakultas Kelautan dan Perikanan Universitas Udayana.

\subsection{Alat dan bahan}

Adapun alat yang digunakan dalam penelitian ini yaitu : GPS, oven, timbangan analitik, botol sampel, pengaduk magnetic, pipet volume, gelas ukur, cawan alumunium, penjepit, pompa vacuum. Sedangkan bahan yang digunakan dalam penelitian ini yaitu : glove, kertas saring (pore 2.5 $\mu \mathrm{m})$, tissue, akuades.

\subsection{Pengambilan sampel TSS}

Pengambilan sampel TSS dilakukan pada kondisi perairan surut menuju pasang dan pasang menuju surut. Sampel air yang telah diambil kemudian dimasukkan kedalam cool box dengan suhu $<4^{\circ} \mathrm{C}$. Ini dilakukan untuk meminimalkan dekomposisi mikrobiologikal terhadap padatan yang dapat menganggu dalam proses analisis TSS.

Pengambilan sampel TSS di Bulan Januari dilaksakan pada tanggal 27 Januari 2016 dengan kondisi perairan dari surut menuju pasang dan pasang menuju surut yaitu pada pukul 08.00 12.00 wita untuk surut menuju pasang dan pada pukul 13.00 - 16.00 wita untuk pasang menuju surut (Gambar 2). Pemilihan waktu pengambilan sampel dilakukan berdasarkan data prediksi pasang surut yang dikeluarkan oleh TNI AL Hidro-oseanografi (2016) dengan mempertimbangan elevasi pasang surut yang tidak rendah serta waktu pengambilan yang bisa dilakukan saat pagi hari.

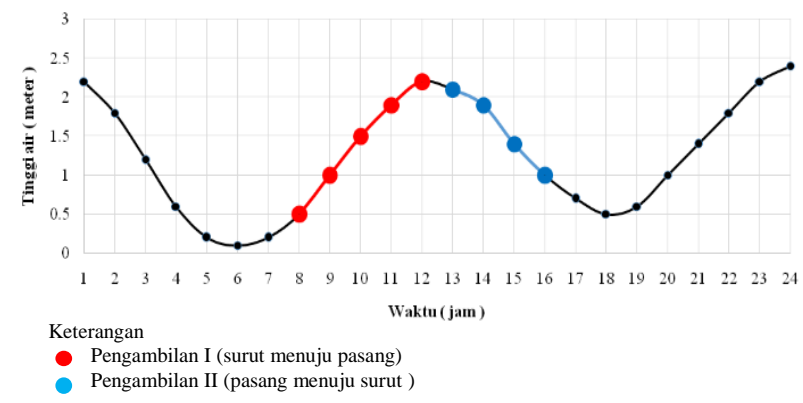

Gambar 2. Grafik pasang surut pelabuhan Benoa Bali (TNI AL Hidro-oseanografi, 2016)

\subsection{Analisis data}

\subsubsection{Total Padatan Tersuspensi}

Sampel diuji dan dianalisis di laboratorium Fakultas Kelautan dan Perikanan Universitas Udayana. Metode yang digunakan dalam analisa sampel dan persamaan mengikuti prosedur 
Standar Nasional Indonesia (SNI) No. 06-6989.32004 tentang cara uji padatan tersuspensi total secara gravimetri. Persamaan tersebut yaitu:

$$
\text { TSS per Liter }=\frac{(A-B) \times 1000}{\text { Volume Uji mL }}
$$

Dimana A adalah berat kertas saring akhir (mg) dan $B$ adalah berat kertas saring awal (mg).

Untuk menjamin validitas pengukuran TSS, maka dalam penelitian ini juga akan dilakukan penjaminan terhadap mutu dan pengendalian terhadap mutu proses-proses analisis TSS. Untuk jaminan mutu, maka beberapa hal akan diperhitungkan yaitu:

a. Menggunakan alat gelas bebas kontaminasi dengan sterilisasi menggunakan aquades;

b. Menggunakan alat ukur yang terkalibrasi; dan

c. Melakukan analisis dalam jangka waktu yang tidak melampaui waktu simpan maksimum 24 jam.

Dan untuk melakukan pengendalian mutu maka akan memperhatikan proses sebagai berikut:

a. Melakukan analisis blanko untuk kontrol kontaminasi; dan

b. Melakukan analisis duplo yang digunakan untuk mengkontrol ketelitian analisis. Perbedaan persen relatif (Relative Percent Different atau RPD) terhadap dua penentuan (replikasi) adalah dibawah 5\%, dengan menggunakan persamaan 2:

$$
R P D=\frac{\left(X_{1}-X_{2}\right)}{\left(X_{1}+X_{2}\right) / 2} \times 100 \%
$$

dimana $X_{1}$ adalah kandungan padatan tersuspensi pada penentuan pertama. $\mathrm{X}_{2}$ adalah kandungan padatan tersuspensi pada penentuan ke dua. Bila nilai RPD lebih besar $5 \%$, penentuan ini akan diulang.

\subsubsection{Distribusi spasial Total Padatan Tersuspensi}

Analisis distribusi spasial total padatan tersuspensi menggunakan metode interpolasi Inverse Distance Weighted (IDW). Dimana interpolasi dengan metode ini memiliki keuntungan penggunaan yang lebih mudah dan efisien. Software yang digunakan untuk membantu pengolahan spasial total padatan tersuspensi yaitu menggunakan software QGIS 2.4 dengan nilai power 4. Analisis distribusi spasial ditampilkan berupa peta pada kondisi perairan mulai dari pasang menuju surut dan surut menuju pasang.

\section{Hasil dan Pembahasan}

\subsection{Analisis duplo}

Pengujian analisis yang telah dilaksanakan didapatkan rata-rata persentase analisis duplo pada bulan Januari yaitu 3.37\%. Perbedaan persen relatif (Relative Percent Different atau RPD) terhadap dua penentuan (replikasi) sesuai dengan acuan Standar Nasional Indonesia (SNI) No. 066989.3-2004 tentang cara uji padatan tersuspensi total secara gravimetri adalah dibawah 5\% sehingga hasil analisis duplo menunjukan bahwa tingkat ketelitian saat analisis TSS sudah baik.
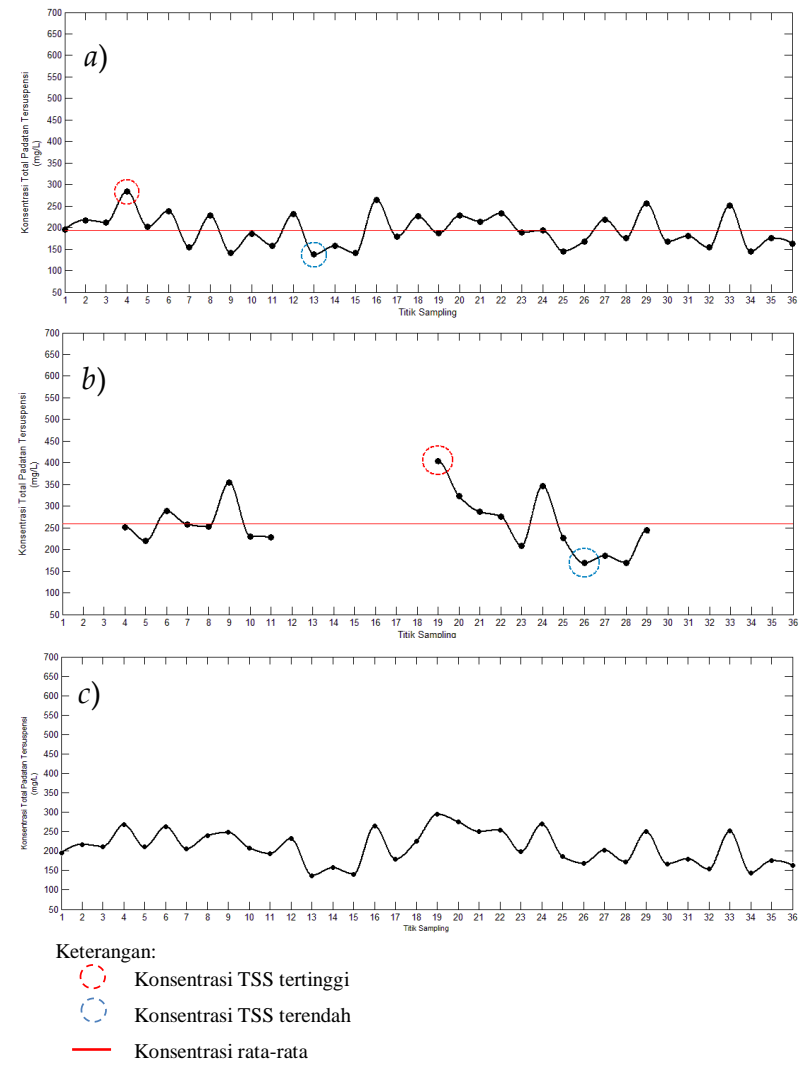

Gambar 3. Konsentrasi TSS di permukaan teluk Benoa. (a) surut menuju pasang. (b) pasang menuju surut. (c) Rata-rata

\subsection{Distribusi spasial TSS}

Pada pengambilan sampel air di bulan Januari terkendala oleh kondisi cuaca. Dimana kondisi cuaca saat pengambilan sampel yaitu hujan dengan intensitas tinggi yang disertai dengan hembusan angin yang kencang, sehingga hanya diperoleh sampel air berjumlah 19 titik dari 36 titik pengambilan sampel. Berdasarkan hasil analisis TSS yang telah dilakukan pada saat surut menuju 
pasang, konsentrasi rata-rata konsentrasi TSS sebesar $194.15 \pm 39.22 \mathrm{mg} / \mathrm{l}$ dengan konsentrasi TSS tertinggi sebesar $284.22 \mathrm{mg} / \mathrm{L}$ terdapat di titik 4 dan terendah sebesar $137.11 \mathrm{mg} / \mathrm{L}$ terdapat di titik 13 (Gambar 3a). Pada saat pasang menuju surut Konsentrasi rata-rata TSS sebesar $258.99 \pm 63.53$ $\mathrm{mg} / \mathrm{L}$ dengan konsentrasi tertinggi sebesar 403.33 $\mathrm{mg} / \mathrm{L}$ terdapat di titik 19 dan terendah sebesar $168.44 \mathrm{mg} / \mathrm{L}$ terdapat di titik 26 (Gambar 3b). Sedangkan Rata-rata nilai TSS yang didapatkan dari perataan saat kondisi surut menuju pasang dan pasang menuju surut di bulan Januari. Diperoleh hasil dengan konsentrasi TSS tertinggi sebesar $294.89 \mathrm{mg} / \mathrm{L}$ terdapat di titik 19 dan terendah sebesar $137.11 \mathrm{mg} / \mathrm{L}$ terdapat di titik 13 (Gambar 3c).

Tingginya konsentrasi TSS di titik 4 diduga diakibatkan oleh lokasi titik sampling yang berada di sekitar mulut sungai. Seperti halnya penelitian yang dilakukan oleh Lestari (2009) dan Wisha and Ondara (2017) di perairan Teluk Jakarta dan Perairan Sayung, Demak yang memperoleh konsentrasi TSS tertinggi terdapat di sekitar muara sungai. Namun pada titik 13 konsentrasi TSS paling rendah diduga diakibatkan oleh berpindahnya polutan yang diakibatkan oleh pola arus Teluk Benoa. Pada kondisi pasang menuju surut terdapat konsentrasi TSS yang paling tinggi yaitu pada titik 19 yang terdapat di bagian tengah teluk. Tingginya konsentrasi TSS di bagian tengah teluk diduga diakibatkan oleh pola arus yang terjadi saat kondisi pasang menuju surut, dimana terjadi perpindahan lokasi polutan. Seperti halnya penelitian yang dilakukan oleh Ardana dan Mahendra (2012) yang menyebutkan bahwa pada kondisi pasang menuju surut arah arus keluar menuju laut lepas. Arah arus yang keluar menuju laut lepas berpotensi memindahkan polutan yang ada di muara sungai, sehingga polutan di muara sungai menjadi lebih kecil.

Konsentrasi TSS pada kondisi surut menuju pasang dan pasang menuju surut sudah melebihi ambang baku mutu yang telah ditetapkan dalam peraturan Gubernur Bali no. 8 tahun 2007 tentang baku mutu lingkungan hidup dan kriteria baku kerusakan lingkungan hidup (Tabel 1).

\section{Tabel 1}

Baku mutu TSS.

\begin{tabular}{cll}
\hline No & \multicolumn{1}{c}{ Jenis Kegiatan } & \multicolumn{1}{c}{ Nilai TSS } \\
\hline 1 & Wisata Bahari & $20 \mathrm{mg} / \mathrm{L}$ \\
2 & Biota laut & Coral $20 \mathrm{mg} / \mathrm{L}$ \\
& & Lamun $20 \mathrm{mg} / \mathrm{L}$ \\
& & Mangrove $80 \mathrm{mg} / \mathrm{L}$ \\
3 & Pelabuhan & $80 \mathrm{mg} / \mathrm{L}$ \\
4 & Budidaya perikanan & $80 \mathrm{mg} / \mathrm{L}$ \\
\hline
\end{tabular}

Berdasarkan peta persebaran TSS di perairan Teluk Benoa pada kondisi surut menuju pasang di bulan Januari (Gambar 4), konsentrasi TSS tertinggi terdapat di bagian Timur Laut, Barat,

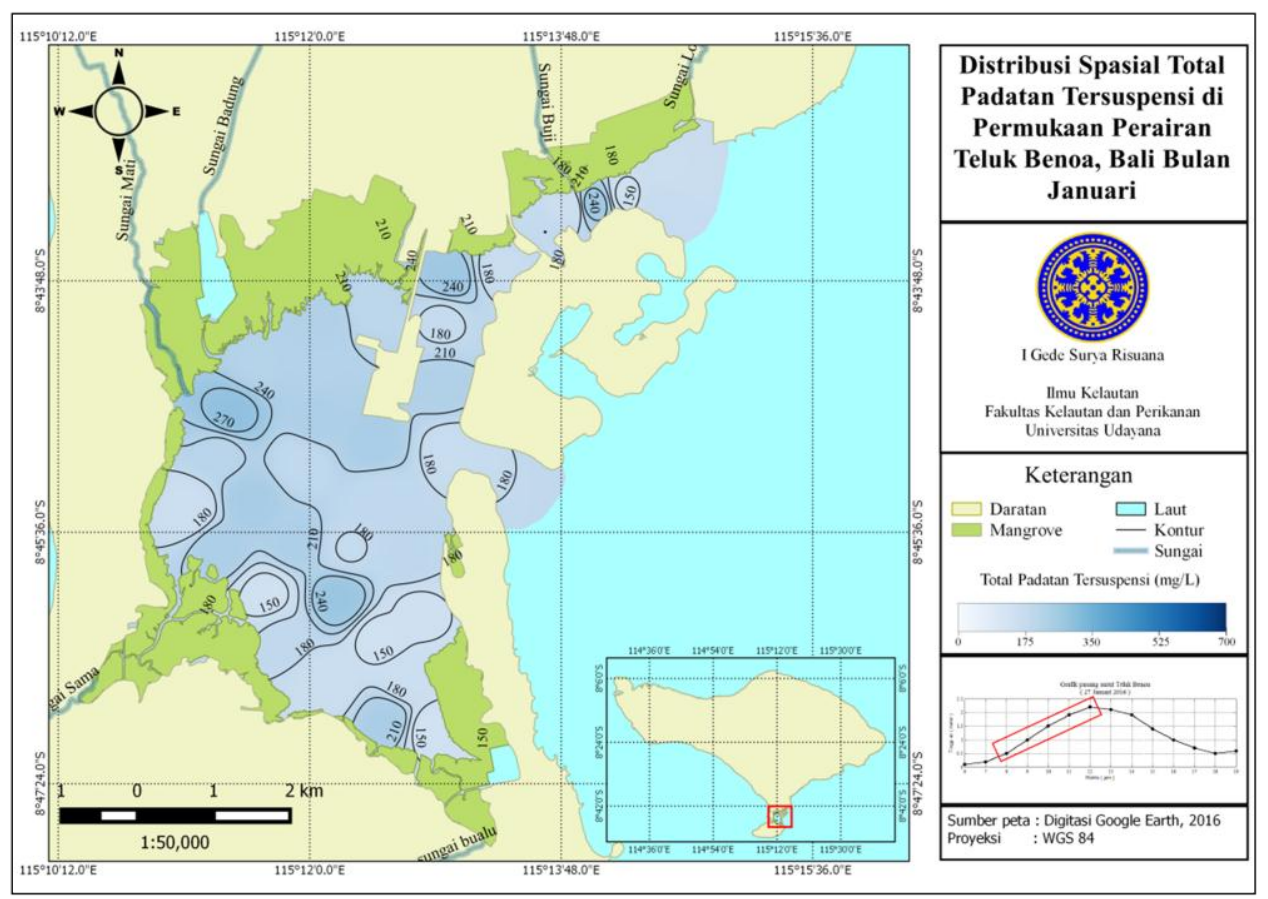

Gambar 4. Distribusi spasial TSS di permukaan perairan teluk Benoa Bali kondisi surut menuju pasang 


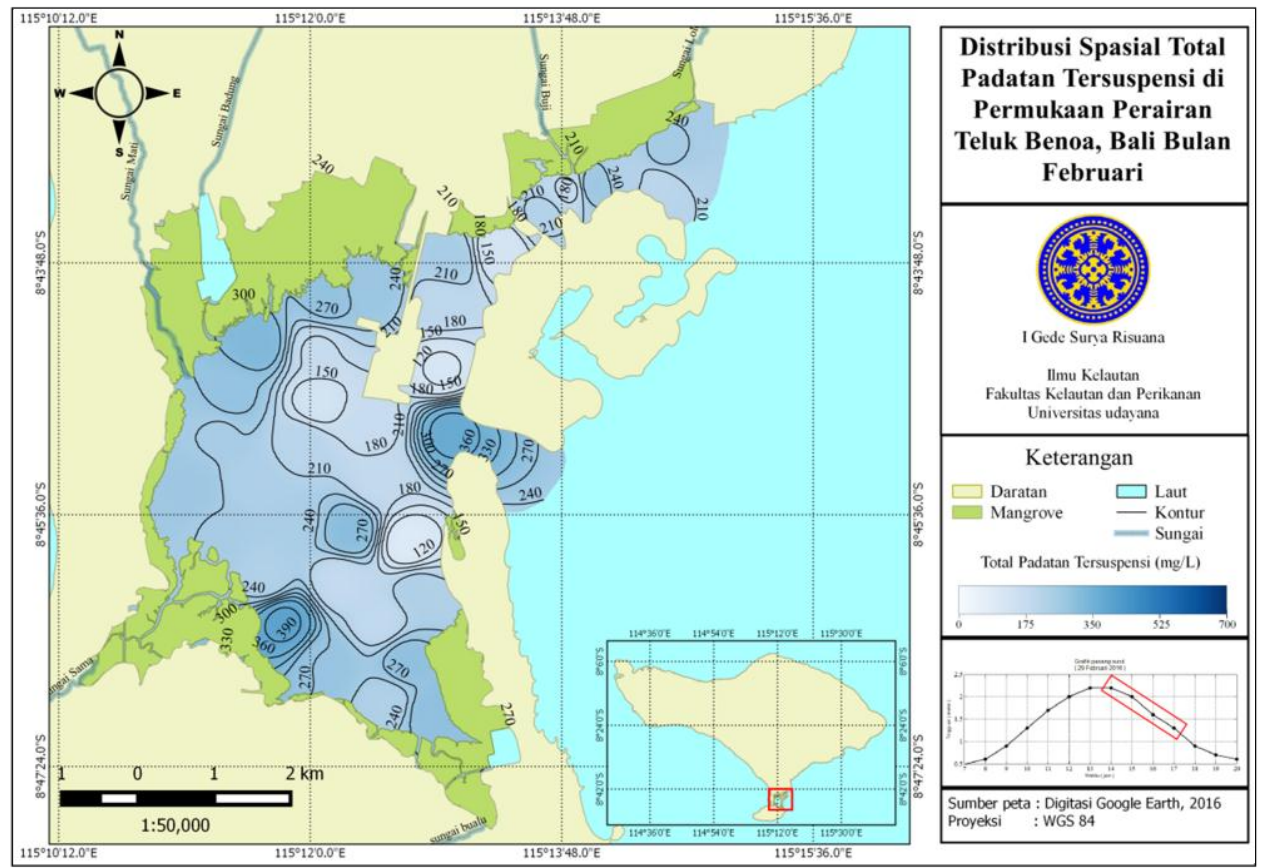

Gambar 5. Distribusi spasial TSS di permukaan perairan teluk Benoa Bali kondisi pasang menuju surut

Barat Daya, dan Selatan teluk. Pada bagian Timur Laut teluk konsentrasi tertinggi terdapat di sekitar muara sungai Buji. Namun pada muara sungai Loloan dan mulut teluk bagian Timur Laut konsentrasi TSS cenderung lebih rendah dari pada di muara sungai Buji. Pada bagian barat teluk konsentrasi TSS tertinggi terdapat pada muara sungai Mati dan muara sungai Badung, namun konsentrasi yang lebih rendah terdapat pada sungai Badung. Pada bagian Barat daya teluk konsentrasi TSS tertinggi terdapat pada muara sungai Sama hingga menuju ke bagian Barat teluk. Pada bagian Selatan teluk konsentrasi TSS tertinggi terdapat di sekitar muara sungai Bualu. Pada bagian tengah teluk dan timur teluk konsentrasi TSS cenderung lebih rendah dari pada bagian teluk lainnya.

Persebaran konsentrasi TSS tertinggi saat kondisi surut menuju pasang di bulan Januari hingga bulan Maret cenderung berada di sekitar muara sungai. Seperti halnya penelitian yang dilakukan oleh Helfinalis (2005) di perairan penimbang dan Kusuardini (2011) di perairan teluk Jakarta yang memperoleh kandungan TSS tertinggi berada di sekitar muara sungai. Menurut Lestari (2009) tingginya TSS di sekitar muara sungai diakibatkan oleh masuknya bahan-bahan tersuspensi dari daratan yang terbawa oleh aliran sungai. Teluk Benoa memiliki beberapa sungai besar yang bermuara di Teluk Benoa. Sungai tersebut melintasi perkotaan yang padat dengan aktifitas yang sangat tinggi sehingga berpotensi akan mengakibatkan banyaknya masukan bahan tersuspensi yang terbawa oleh aliran sungai tersebut. Namun terdapat beberapa lokasi yang tidak tepat berada di muara sungai hal tersebut diduga diakibatkan oleh arah arus laut di lokasi tersebut yang menyebabkan polutan berpindah lokasi. Sama seperti pendapat Sukarno dan Yusuf (2013) yang mengatakan persebaran TSS sangat di pengaruhi oleh pola arus laut. Pada bagian mulut teluk bagian utara dan selatan konsentrasi TSS lebih rendah dari pada lokasi lainnya. Rendahnya konsentrasi TSS di bagian mulut teluk diduga karena kandungan TSS akan semakin rendah kearah laut lepas yang diakibatkan terjadinya pengenceran polutan. Hal ini sesuai dengan pendapat Hendrawan dkk. (2016), Irawati (2011) dan Winarsih (2016) yang menunjukkan bahwa konsentrasi TSS mengalami penurunan ke arah laut yang diakibatkan oleh adanya pengenceran oleh air laut ketika material tersebut mencapai laut. Menurut Hendrawan dan Asai (2014) pada kondisi surut menuju pasang arah arus di Teluk Benoa masuk menuju ke dalam teluk. Hal ini mengakibatkan konsentrasi TSS tertinggi di dominasi terdapat di sekitar muara-muara sungai yang diakibatkan oleh masuknya masa air laut yang terdapat di luar teluk menuju dalam teluk sehingga masa air yang berada di dalam teluk akan terdorong dan akan menyebabkan terhambatnya pembilasan menuju laut lepas. 

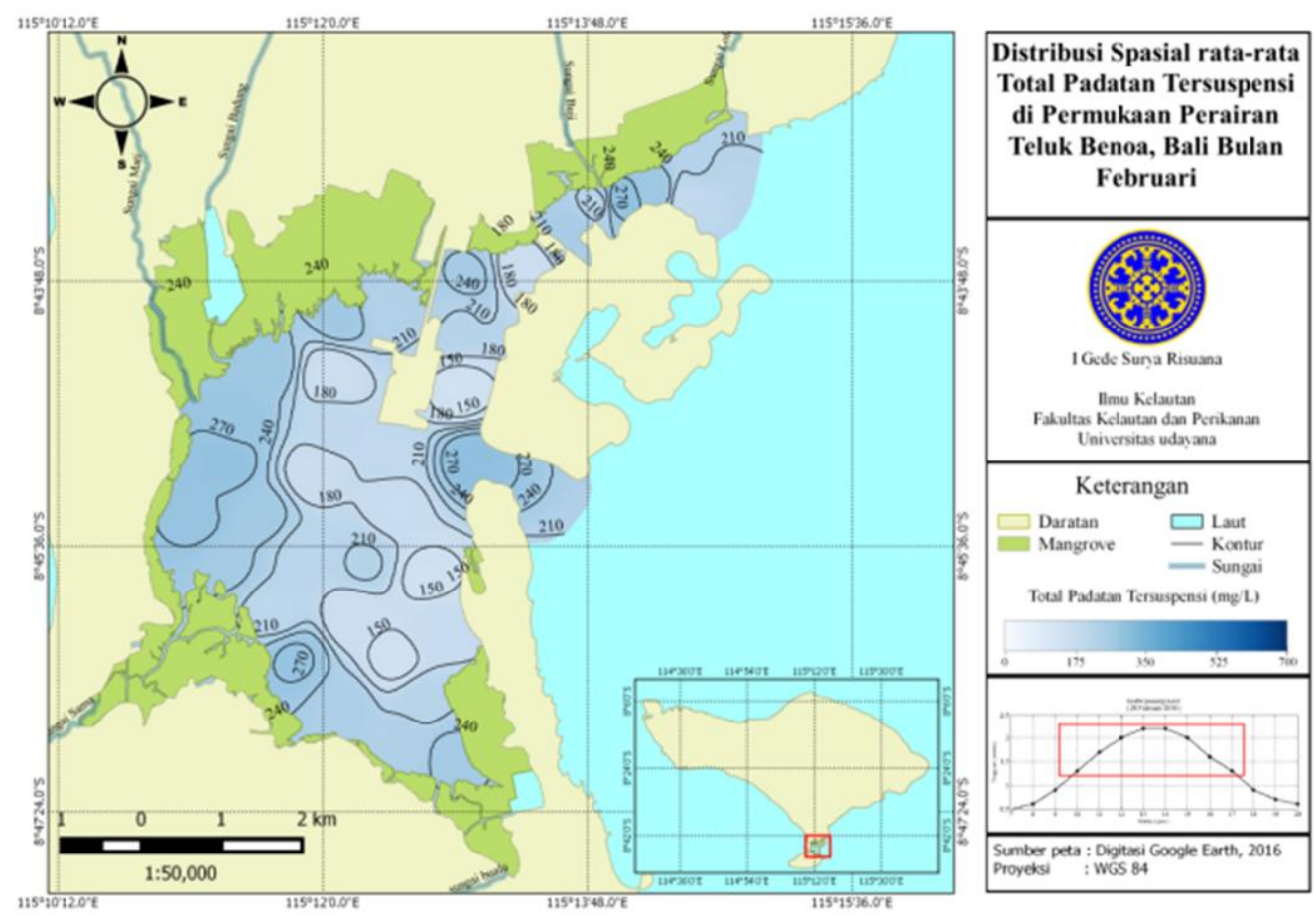

Gambar 6. Distribusi spasial TSS rata-rata di permukaan perairan teluk Benoa Bali

Berdasarkan peta persebaran TSS di bulan Januari (Gambar 5), konsentrasi TSS tertinggi terdapat pada bagian tengah teluk. Pada bagian Timur Laut teluk terdapat data yang tidak diperoleh karena saat pengambilan data terjadi hujan yang lebat. Sehingga hasil interpolasi di bagian timur laut teluk menjadi kurang baik. Pada bagian Barat teluk konsentrasi TSS cenderung lebih rendah dari pada bagian tengah teluk. Pada bagian Barat Daya teluk konsentrasi TSS tertinggi terdapat pada muara sungai Sama. Namun nilai tertinggi di dominasi terdapat pada bagian tengah teluk. Sedangkan pada bagian timur teluk konsentrasi TSS cenderung lebih rendah dari pada bagian teluk lainnya.

Persebaran konsentrasi TSS tertinggi saat kondisi pasang menuju surut di bulan Januari cenderung berada di sekitar muara sungai dan pada mulut teluk. Seperti halnya pada kondisi surut menuju pasang persebaran TSS juga berada di bagian muara sungai. Namun konsentrasi tertinggi terdapat juga di bagian mulut teluk. Hal ini dapat diakibatkan oleh pola pergerakan arus di teluk Benoa. Menurut Hendrawan dan Asai (2014) pada saat pasang menuju surut pola arus di Teluk Benoa menuju ke luar teluk, sehingga konsentrasi TSS akan lebih tersebar di tengah.

Persebaran rata-rata konsentrasi TSS tertinggi pada bulan Januari didominasi terdapat pada utara, barat, dan selatan teluk. Pada bagian utara teluk konsentrasi TSS tertinggi terdapat pada muara sungai Buji. Pada bagian barat teluk konsentrasi TSS tertinggi terdapat pada muara sungai Sama. Pada bagian selatan teluk konsentrasi tertinggi terdapat pada muara sungai Sama dan muara sungai Bualu. Pada bagian tengah konsentrasi TSS cenderung tinggi namun terdapat beberapa bagian teluk yang rendah. Pada bagian timur teluk konsentrasi TSS cenderung lebih rendah dari pada daerah lainnya (Gambar 6).

Hasil rata-rata pada bulan Januari saat kondisi surut menuju pasang dan pasang menuju surut didominasi konsentrasi tertinggi terdapat di sekitar muara sungai dan mulut teluk. Tingginya konsentrasi Total Padatan Tersuspensi di Teluk Benoa diduga diakibatkan oleh beberapa faktor yaitu faktor fisik dan faktor biologi. Faktor fisik yang mempengaruhi konsentrasi TSS diakibatkan oleh kecepatan partikel dalam menetap di dasar perairan serta kecepatan aliran (Beschta dan Jackson, 1979 in Branigan, 2013), selain itu terjadinya badai, kecepatan angin, dan pasang surut juga merupakan faktor fisika yang mempengaruhi konsentrasi TSS (Branigan, 2013). Faktor biologi yang mempengaruhi konsentrasi TSS yaitu tingginya klorofil-a dalam suatu perairan. Seperti penelitian yang dilakukan oleh Kusuardini (2011) yang mengatakan bahwa terjadi korelasi positif yang kuat antara TSS dan klorofila. 


\subsection{TSS sungai yang bermuara di teluk Benoa}

Pengambilan data TSS sungai yang bermuara di teluk Benoa pada bulan Januari dilakukan bersamaan dengan pengambilan sampel di dalam teluk. Berdasarkan hasil analisis yang telah dilakukan konsentrasi TSS tertinggi saat surut menuju pasang yaitu sebesar $201.77 \mathrm{mg} / \mathrm{L}$ terdapat pada sungai Bualu dan terendah sebesar $24 \mathrm{mg} / \mathrm{L}$ terdapat pada sungai Buji. Pada saat pasang menuju surut konsentrasi TSS tertinggi sebesar $261.33 \mathrm{mg} / \mathrm{L}$ terdapat pada sungai Sama dan terendah sebesar $22.44 \mathrm{mg} / \mathrm{L}$ terdapat pada sungai Badung. Rata-rata konsentrasi TSS saat surut menuju pasang dan pasang menuju surut diperoleh dengan konsentrasi tertinggi sebesar 224 $\mathrm{mg} / \mathrm{L}$ terdapat pada sungai Bualu dan terendah sebesar $31 \mathrm{mg} / \mathrm{L}$ terdapat pada sungai Buji (Gambar 7).

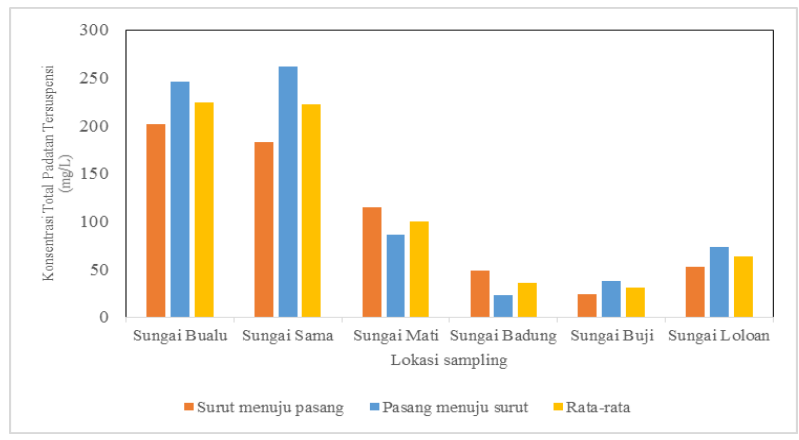

Gambar 7. Konsentrasi TSS sungai yang bermuara di teluk Benoa pada bulan Januari

Tabel 2

Baku mutu TSS pada Sungai.

\begin{tabular}{clc}
\hline No & \multicolumn{1}{c}{ Kelas } & Nilai TSS \\
\hline 1 & $\begin{array}{l}\text { Kelas I } \\
\text { (air minum ) }\end{array}$ & $50 \mathrm{mg} / \mathrm{L}$ \\
2 & $\begin{array}{l}\text { Kelas II } \\
\text { (sarana rekreasi air, pembudidayaan }\end{array}$ & $50 \mathrm{mg} / \mathrm{L}$ \\
& $\begin{array}{l}\text { ikan air tawar, peternakan, air untuk } \\
\text { mengairi pertanaman) }\end{array}$ \\
3 & $\begin{array}{l}\text { Kelas III } \\
\text { (pembudidayaan ikan air tawar, } \\
\text { peternakan, air untuk mengairi } \\
\text { pertanaman) } \\
\text { Kelas IV } \\
\text { (Mengairi tanaman) }\end{array}$ & $400 \mathrm{mg} / \mathrm{L}$ \\
\hline & & $400 \mathrm{mg} / \mathrm{L}$ \\
\hline
\end{tabular}

Berdasarkan hasil yang telah diperoleh menunjukkan bahwa konsentrasi TSS di beberapa sungai melebihi ambang baku mutu yang telah ditetapkan dalam peraturan Pemerintah Republik Indonesia no 82 tahun 2001 tentang pengelolaan kualitas air dan pengendalian pencemaran air (Tabel 2). Pada kondisi surut menuju pasang sungai yang melebihi ambang baku mutu terdapat pada sungai Bualu, sungai Sama, dan sungai Mati. Pada kondisi pasang menuju surut sungai yang melebihi ambang baku mutu terdapat pada Bualu, sungai Sama, sungai Mati dan sungai Loloan.

Perbedaan yang signifikan pada sungai Sama dan sungai Bualu diduga diakibatkan oleh adanya pengaruh air laut yang masuk kedalam sungai. Seperti halnya yang dikemukakan oleh Kementerian lingkungan hidup dan kehutanan (2015) yang menyatakan bahwa sungai Sama dan sungai Bualu merupakan sungai intermiten atau sungai yang terdapat aliran pada saat musim hujan saja sehingga dapat dikatakan bahwa inputan air tawar yang sangat kecil. Selain itu titik pengambilan sampel di sungai Bualu dan sungai Sama merupakan daerah yang bersubstrat lumpur sehingga berpotensi memberikan sumbangan konsentrasi TSS yang tinggi. Pada sungai Mati sungai Badung, sungai Buji dan sungai Loloan menunjukan konsentrasi yang lebih rendah daripada sungai Bualu dan sungai Sama hal tersebut diduga diakibatkan oleh rendahnya masukan air laut di sungai tersebut. Selain itu rendahnya konsentrasi TSS di sungai tersebut diduga diakibatkan cepatnya pembilasan sungai.

\section{Simpulan}

Konsentrasi TSS pada bulan Januari pada saat surut menuju pasang dan pasang menuju surut berkisar antara $137.11 \mathrm{mg} / \mathrm{L}$ hingga mencapai $403.33 \mathrm{mg} / \mathrm{L}$. konsentrasi TSS di sungai yang bermuara di Teluk Benoa berkisar antara 22.44 mg/L hingga mencapai $261.33 \mathrm{mg} / \mathrm{L}$. Persebaran konsentrasi TSS tertinggi pada saat surut menuju pasang didominasi terdapat di sekitar muara sungai yang bermuara di Teluk Benoa. Tingginya konsentrasi di sekitar muara diduga dikibatkan oleh adanya masukkan bahan-bahan tersuspensi dari daratan yang terbawa oleh aliran sungai. Pada kondisi pasang menuju surut konsentrasi TSS tertinggi terdapat di sekitar muara sungai, bagian tengah teluk dan bagian mulut teluk. Tinggi konsentrasi TSS di bagian tengah teluk dan mulut telu diduga diakibatkan oleh pola pergerakan arus di teluk Benoa. Dimana pada saat pasang menuju surut pola arus di Teluk Benoa menuju ke luar teluk, sehingga konsentrasi TSS akan lebih tersebar di tengah teluk hingga ke luar teluk. 


\section{Ucapan terimakasih}

Penulis mengucapkan terima kasih kepada rekanrekan mahasiswa Fakultas Kelautan dan Perikanan Universitas Udayana atas bantuannya selama pengambilan data.

\section{Daftar Pustaka}

Ardana, K., \& Mahendra, M. S. (2012). Study of pollutant distribution in Benoa Bay using numerical simulation and satellite data. Ecotrophic: Journal of Environmental Science, 3(2), 81-86.

Azpurua, M. A., \& Ramos, K. D. (2010). A comparison of spatial interpolation methods for estimation of average electromagnetic field magnitude. Progress In Electromagnetics Research M, 14, 135-145.

Bilotta, G. S., \& Brazier, R. E. (2008). Understanding the influence of suspended solids on water quality and aquatic biota. Water research, 42(12), 2849-2861.

Dinas Hidro-oseanografi. (2016). Daftar pasang surut tide tables tahun 2016. Jakarta, Indonesia: Dinas Hidro-oseanografi TNI AL.

Toy, T. J., Foster, G. R., \& Renard, K. G. (2002). Soil Erosion, Processes, Prediction, Measurement and Control. New York, USA: John Wiley and Sons, Inc.,

Helfinalis. (2005). Kandungan total suspended solid dan sedimen di dasar perairan penimbang. Makara Sains, 9(2), 45-51.

Hendrawan, I. G., \& Asai, K. (2014). Numerical study on tidal currents and seawater exchange in the Benoa Bay, Bali, Indonesia. Acta Oceanologica Sinica, 33(3), 90-100.

Hendrawan, I. G., Uniluha, D., \& Maharta, I. P. R. F. (2016). Karakteristik Total Padatan Tersuspensi (Total Suspended Solid) Dan Kekeruhan (Turbidity) Secara Vertikal Di Perairan Teluk Benoa, Bali. Journal of Marine and Aquatic Sciences, 2(1), 29-33.

Hendrawan, G., Nuarsa, I. W., Sandi, W., Koropitan, A. F., \& Sugimori, Y. (2005). Numerical Calculation for the Residual Tidal Current in Benoa Bay-Bali Island. International Journal of Remote Sensing and Earth Sciences, 2, 86-93.

Irawati, N. (2011). Hubungan produktivitas primer fitoplankton dengan ketersediaan usur hara pada berbagai tingkat kecerahan di teluk Kendari Sulawesi Tenggara. Skripsi. Bogor, Indonesia: Mayor Pengelolaan Sumberdaya Perairan, Sekolah Pascasarjana, Institut Pertanian Bogor.

Kusuardini, A. (2011). Estimasi konsentrasi padatan tersuspensi (TSS) dan klorofil-a dari citra modis hubungannya dengan marak alga di perairan teluk Jakarta. Skripsi. Bogor, Indonesia: Departemen Ilmu dan Teknologi Kelautan, Fakultas Perikanan dan Ilmu Kelautan, Institut Pertanian Bogor.
Lestari, I. B. (2009). Pendugaan konsentrasi Total Suspended Solid (TSS) dan transparansi perairan Teluk Jakarta dengan citra satelit landsat. Skripsi. Bogor, Indonesia. Fakultas Perikanan dan Ilmu Kelautan. Institut Pertanian Bogor.

Li, J., \& Heap, A. D. (2014). Spatial interpolation methods applied in the environmental sciences: A review. Environmental Modelling \& Software, 53, 173189.

Marganof, D. L., Riani, E., \& Pramudya, B. (2007). Analisis beban pencemaran, kapasitas asimilasi dan tingkat pencemaran dalam upaya pengendalian pencemaran perairan Danau Maninjau. Jurnal Perikanan dan Kelautan, 12(1), 8-14.

Mitchell, M. K., \& Stapp, W. B. (2008). Field manual for water quality monitoring: an environmental education program for schools. (13th ed.). Iowa, USA: Kendall/Hunt Publishing Company.

Ohrel, R. L., \& Register, K. M. (2006). Volunteer estuary monitoring: a methods manual. (2nd Ed.). Washington DC, USA: The Ocean Conservancy and U.S. Environmental Protection Agency.

Pemprov Bali. (2007). Peraturan Gubernur Bali Nomor 8 Tahun 2007 tentang Baku Mutu Lingkungan Hidup Dan Kriteria Baku Kerusakan Lingkungan Hidup. Denpasar, Indonesia: Pemerintah Daerah Provinsi Bali.

Pramono, G. H. (2008). Akurasi metode IDW dan Kriging untuk interpolasi sebaran sedimen tersuspensi di Maros, Sulawesi Selatan. Forum Geografi, 22(2), 145-158.

Republik Indonesia. (2011). Peraturan Pemerintah Nomor 82 Tahun 2001 tentang Pengelolaan Kualitas Air Dan Pengendalian Pencemaran Air. Lembaran Negara Republik Indonesia Tahun 2001 Nomor 153. Jakarta, Indonesia: Sekretariat Negara Republik Indonesia.

Indonesia SNI. (2004). SNI Nomor 06-6989.3-2004 tentang Air dan air limbah-Bagian 3: Cara uji padatan tersuspensi total (Total Suspended Solid, TSS) secara gravimetri. Jakarta, Indonesia: Badan Standardisasi Nasional.

Sudiarta, K., Hendrawan, G., Putra, K. S., \& Dewantama, I. M. D. (2013). Kajian modeling dampak perubahan fungsi teluk Benoa untuk system pendukung keputusan (Decision Support System) dalam jejaring KKP Bali. Denpasar, Indonesia: Conservation International Indonesia (CII) Bali.

Sukarno, M., \& Yusuf, M. (2013). Kondisi Hidrodinamika Dan Pengaruhnya Terhadap Sebaran Parameter Fisika-Kimia Perairan Laut Dari Muara Sungai Porong, Sidoarjo. Buletin Oseanografi Marina, 2(2), 1-6.

Suriawiria, U. (1996). Air dalam Kehidupan dan Lingkungan yang Sehat. Alumni. Bandung, Indonesia: Penerbit Alumni.

Winnarsih, W., Emiyarti, E. \& Afu, L. O. A.(2016). Distribusi Total Suspended Solid Permukaan Di 
Perairan Teluk Kendari. Jurnal Sapa Laut (Jurnal Ilmu Kelautan), 1(2), 54-59.

Xie, Y., Chen, T. B., Lei, M., Yang, J., Guo, Q. J., Song, B., \& Zhou, X. Y. (2011). Spatial distribution of soil heavy metal pollution estimated by different interpolation methods: accuracy and uncertainty analysis. Chemosphere, 82(3), 468-476.

Wilber, D. H., \& Clarke, D. G. (2001). Biological effects of suspended sediments: a review of suspended sediment impacts on fish and shellfish with relation to dredging activities in estuaries. North American Journal of Fisheries Management, 21(4), 855-875.

Wisha, U. J., \& Ondara, K. (2017). Total Suspended Solid (TSS) Distributed by Tidal Currents during Low to High Tide Phase in the Waters of Sayung, Demak: Its Relations to Water Quality Parameters. Journal of Marine and Aquatic Sciences, 3(2), 154-162.

(C) 2017 by the authors; licensee Udayana University, Indonesia. This article is an open access article distributed under the terms and conditions of the Creative Commons Attribution license (http://creativecommons.org/licenses/by/3.0/). 